Acta vet. scand. $1977,18,397-407$.

From the State Veterinary Medical Institute, Helsinki, and the Food Research Laboratory, Technical Research Centre of Finland, Espoo.

\title{
COMPARATIVE STUDIES OF BACILLUS CEREUS STRAINS ISOLATED FROM VARIOUS FOODS AND FOOD POISONING OUTBREAKS
}

\author{
By \\ M. Raevuori, T. Kiutamo and A. Niskanen
}

RAEVUORI, M., T. KIUTAMO and A. NISKANEN: Comparative studies of Bacillus cereus strains isolated from various foods and food poisoning outbreaks. Acta vet. scand. 1977, 18, 397-407. - Certain properties of 22 Bacillus cereus strains isolated from different foods and food poisoning episodes were investigated in order to evaluate possible differences between strains isolated from diarrhoeal and vomiting type food poisoning outbreaks.

None of the strains isolated from vomiting type episodes produced acid from salicin and mannose, whereas 80 and $40 \%$ of the strains from diarrhoeal type outbreaks were positive, respectively. No association between the antibiotic sensitivity pattern or the fatty acid composition and the source of a strain could be found, although some strains differed from the general pattern of B. cereus in some instances. No significant differences in the production of the skin factor between strains isolated from the two types of outbreaks were found either. The findings of this study support the observation that the food environment itself essentially affects the enterotoxin formation of B. cereus.

bacillus cereus; food poisoning; enterotoxin; antibiotic sensitivity; fatty acid composition; skin test.

Bacillus cereus is known to be the causative agent of two distinct types of food poisoning. The older and therefore better known type is characterized by diarrhoea, abdominal pain and an incubation time of from 8 to $16 \mathrm{hrs}$. The first report of an outbreak with diarrhoeal type syndromes evidently caused by B. cereus was published by Lubenau in Germany (Lubenau 1906). The first detailed description of this type of food poisoning, however, was published by Hauge in Norway no earlier than 1950 (Hauge 1950). Different foods have been implicated in the outbreaks reported from several countries particularly in Europe. 
In 1972 the first report of another type of B. cereus food poisoning, characterized by nausea and vomiting and with an incubation period of only 1 to 5 hrs., was published (Public Health Laboratory Service 1972). Since then several outbreaks of this type have occurred in different countries, including Finland, all associated with the consumption of boiled or fried rice.

Goepfert et al. (1972) and more recently Gilbert \& Taylor (1976) have reviewed the role of $B$. cereus as a food poisoning organism. Some recent reports of outbreaks have not yet been available for review: An episode due to ingestion of vegetable sprouts in the USA (Portnoy et al. 1976), and the rice outbreaks in Canada (Mathias et al. 1976), Netherlands (Beckers 1976), and Finland (Raevuori et al. 1976).

B. cereus is known to produce at least three distinct extracellular toxins: haemolysin, lethal toxin and phospholipase $\mathrm{C}$ (Johnson \& Bonventre 1967). Using the rabbit ligated ileal loop technique, the fact that haemolysin and phospholipase $\mathrm{C}$ do not cause fluid accumulation, as an enterotoxic substance produced by B. cereus does, has been established (Goepfert et al. 1973). This enterotoxic substance, which is protein in nature, is synthesized and secreted during the logarithmic phase of bacterial growth. The enterotoxin has recently been purified both in the USA (Spira \& Goepfert 1975) and the USSR (Ezepchuk \& Fluer 1971, Gorina et al. 1975), but practical serological detection methods are not yet available.

The purpose of this study was to evaluate the possible differences in certain bacteriological characteristics between B. cereus strains isolated from diarrhoeal and vomiting type food poisoning outbreaks as well as other sources. The following criteria were used in the comparison: certain biochemical tests, antibiotic resistance, fatty acid composition of the bacterium, and the formation of the enterotoxic substance, evaluated using the rabbit skin vascular permeability test.

\section{Strains}

\section{MATERIALS AND METHODS}

The bacterial strains used in the study are shown in Table 1. Stock cultures of the organisms on porcelain beads were prepared according to the method of Hunt et al. (1958). 
T a b l e 1. Origins of the 22 B. cereus strains studied.

\begin{tabular}{llll}
\hline Group & Strain number & Source & Country \\
\hline 1 & & & \\
Isolated from & F 4370 & Barbecued chicken & Canada \\
diarrhoeal type & F 4433 & Meat loaf & USA \\
outbreaks & B-4ac & $?$ & USA \\
& VTT 346 & Barbecue oil & Finland \\
& VTT 358 & Jellied meat & Finland \\
2 & & & \\
Isolated from & F 3502 & Fried rice & Great Britain \\
vomiting type & F 3605 & Boiled rice & Great Britain \\
outbreaks & F 4431 & Indonesian rice dish & Netherlands \\
& F 4810 & Vomit & Great Britain \\
& VTT 352 & Boiled rice & Finland \\
3 & & & \\
Isolated from & ATCC 14579 & $?$ (neotype) & USA \\
different sources & ATCC 9139 & $?$ & USA \\
& 2006 & $?$ & USA \\
& 01552 & $?$ & USA \\
& A-1 & $?$ & USA \\
& VTT 305 & $?$ & Finland \\
& VTT 329 & Caseinate & Finland \\
& VTT 331 & Smoked fish & Finland \\
& VTT 332 & $?$ & Norway \\
& VTT 354 & Rice & Finland \\
& VTT 355 & Garlic salt & Finland \\
& VTT 356 & White pepper & Finland \\
\hline
\end{tabular}

\section{Bacteriological methods}

Generally accepted methods and growth media were used. The media were prepared in the State Veterinary Medical Institute. Commercial agar bases were used. The incubation temperature was $37^{\circ} \mathrm{C}$ and the incubation times as follows: blood agar, $24 \mathrm{hrs}$; lecithinase agar, $24 \mathrm{hrs;}$ indole formation, $48 \mathrm{hrs;}$ nitrate reduction, $48 \mathrm{hrs}$; production of acetylmethylcarbinol, 48 hrs; citrate utilization, $48 \mathrm{hrs;}$ production of urease, $24 \mathrm{hrs;}$ motility, $24 \mathrm{hrs}$; and sugar fermentation media, 4 days.

\section{Antibiotic sensitivity}

The sensitivity patterns of the 22 strains for the eight antibiotics shown in Table 3 were analyzed using diagnostic sensitivity test agar plates (Oxoid) and Neo-sensitabs (Rasco, Taa- 
strup, Denmark) disks. The optic densities of the bacterial suspensions used were measured by a spectrophotometer (Unicam SP-600, Cambridge, England) and were found to be between 79.5 and 94.5 at $650 \mathrm{~nm}$ (red filter). These figures corresponded to plate counts $5.8 \times 10^{7}$ and $1.8 \times 10^{7}$, respectively, determined by plating on blood agar. The cultivated disks were incubated for $24 \mathrm{hrs}$. at $37^{\circ} \mathrm{C}$. The length of a single inhibition zone was used as the indicator of antibiotic sensitivity.

\section{Fatty acid composition}

Gas chromatographic analyses of the bacterial fatty acid composition were made using the method of Niskanen et al. (1975).

\section{Enterotoxin production and the skin test}

A method described by Spira \& Goepfert (1975) was used. Brain heart infusion broth (Difco) supplemented with $0.1 \%$ glucose was used as the growth medium. Protein was quantitatively recovered after the ammonium sulphate saturation of the culture filtrate and centrifugation (Sorvall RC2-B, $30 \mathrm{~min}$. at $12840 \times \mathrm{g})$ in a sodium bicarbonate buffer, $\mathrm{pH} 7.9$, in a volume $1 / 100$ that of the original volume of culture filtrate. Assays for the permeability-affecting activity of culture fluids and culture fluid concentrates were made according to a method by Glatz et al. (1974). The New Zealand white rabbits used in the tests weighed 3 to $4 \mathrm{~kg}$. Physiological saline, the growth medium and the buffer solution were used as controls. The mean length of two perpendicular measurements of the radius of an individual skin reaction area was used as the basis for comparative calculations.

\section{RESULTS}

Certain biochemical characteristics of the B. cereus strains studied are shown in Table 2. The sensitivity patterns for the eight antibiotics used in the study of all the 22 strains as well as for the strains originating from diarrhoeal and vomiting types of food poisoning outbreaks are shown in Table 3. Four strains had statistically significant differences $(P<0.05)$ for at least one antibiotic. The length of the inhibitory zone for the individual strains differed from the mean inhibitory zone of all the strains by more than two standard errors in the following cases: 
F 3502, very sensitive to ampicillin and penicillin; F 4370 and VTT 332, very resistant to neomycin; and VTT 356 , very resistant to tetracycline.

T a b l e 2. Certain biochemical characteristics of the B. cereus strains studied.

\begin{tabular}{|c|c|c|c|}
\hline \multirow[b]{2}{*}{ Test } & \multicolumn{3}{|c|}{$\begin{array}{l}\text { Percentage of positive reactions } \\
\text { Pand }\end{array}$} \\
\hline & $\begin{array}{l}\text { (groups 1, } \\
\text { and 3, } \\
\text { Table 1, } \\
\text { n= 22) }\end{array}$ & $\begin{array}{l}\text { from diarrhoeal } \\
\text { type outbreaks } \\
\text { (group 1, Table 1, } \\
\text { n }=5 \text { ) }\end{array}$ & $\begin{array}{l}\text { from vomiting } \\
\text { type outbreaks } \\
\text { group 2, Table 1, } \\
n=5 \text { ) }\end{array}$ \\
\hline Haemolysis of calf blood & 100 & 100 & 100 \\
\hline Production of lecithinase & 100 & 100 & 100 \\
\hline Indole formation & $\mathbf{0}$ & $\mathbf{0}$ & $\mathbf{0}$ \\
\hline Nitrate reduction & 86 & 100 & 80 \\
\hline $\begin{array}{l}\text { Production of acetyl- } \\
\text { methylcarbinol }\end{array}$ & 100 & 100 & 100 \\
\hline Citrate utilization & 100 & 100 & 100 \\
\hline Production of urease & 9 & $\mathbf{0}$ & $\mathbf{0}$ \\
\hline Motility & 100 & 100 & 100 \\
\hline Acid formation from: & & & \\
\hline Adonitol & $\mathbf{0}$ & $\mathbf{0}$ & $\mathbf{0}$ \\
\hline Arabinose & $\mathbf{0}$ & $\mathbf{0}$ & 0 \\
\hline Dulcitol & 0 & 0 & $\mathbf{0}$ \\
\hline Fructose & 91 & 80 & 100 \\
\hline Galactose & $\mathbf{0}$ & 0 & $\mathbf{0}$ \\
\hline Glucose & 100 & 100 & 100 \\
\hline Glycerol & 100 & 100 & 100 \\
\hline Inositol & 0 & 0 & 0 \\
\hline Inuline & 0 & $\mathbf{0}$ & 0 \\
\hline Lactose & $\mathbf{0}$ & $\mathbf{0}$ & 0 \\
\hline Maltose & 5 & $\mathbf{0}$ & 0 \\
\hline Mannitol & 0 & $\mathbf{0}$ & 0 \\
\hline Mannose & 27 & 40 & $\mathbf{0}$ \\
\hline Raffinose & 0 & $\mathbf{0}$ & 0 \\
\hline Rhamnose & 0 & 0 & 0 \\
\hline Saccharose & 64 & 60 & 80 \\
\hline Salicin & 55 & 80 & $\mathbf{0}$ \\
\hline Sorbitol & 0 & 0 & 0 \\
\hline Trehalose & 100 & 100 & 100 \\
\hline Xylose & 0 & 0 & 0 \\
\hline
\end{tabular}

The mean fatty acid compositions in percentages of the strains isolated from diarrhoeal and vomiting types of outbreaks are shown in Table 4. Strain F 4431 differed in its fatty acid com- 
T a b l e 3. Patterns of sensitivity to certain antibiotics of B. cereus strains from different sources.

\begin{tabular}{|c|c|c|c|}
\hline \multirow[b]{2}{*}{$\begin{array}{l}\text { Antibiotic } \\
\text { tested }\end{array}$} & \multicolumn{3}{|c|}{ Lengths of inhibitory zones $(\mathrm{mm})$ (mean $\pm \mathrm{s})$} \\
\hline & $\begin{array}{l}\text { all strains studied } \\
\text { (groups 1,2 } \\
\text { and 3, } \\
\text { Table 1, } \\
\text { n = 22) }\end{array}$ & $\begin{array}{c}\text { strains isolated } \\
\text { from diarrhoeal } \\
\text { type outbreaks } \\
\text { (group 1, Table 1, } \\
\text { n = 5) }\end{array}$ & $\begin{array}{c}\text { strains isolated } \\
\text { from vomiting type } \\
\text { outbreaks } \\
\text { (group 2, Table 1, } \\
\text { n = 5) }\end{array}$ \\
\hline Ampicillin & $2.11 \pm 2.85$ & $1.12 \pm 1.23$ & $5.41 \pm 4.31$ \\
\hline Chloramphenicol & $10.74 \pm 1.00$ & $10.56 \pm 1.41$ & $11.20 \pm 0.84$ \\
\hline Erythromycin & $9.75 \pm 3.08$ & $8.92 \pm 4.45$ & $10.29 \pm 1.61$ \\
\hline Neomycin & $8.99 \pm 0.46$ & $9.35 \pm 0.23$ & $9.02 \pm 0.33$ \\
\hline Penicillin & $0.43 \pm 2.04$ & $0.00 \pm 0.00$ & $1.91 \pm 4.27$ \\
\hline Polymyxin & $0.00 \pm 0.00$ & $0.00 \pm 0.00$ & $0.00 \pm 0.00$ \\
\hline Streptomycin & $8.92 \pm 2.56$ & $7.05 \pm 3.95$ & $9.66 \pm 1.15$ \\
\hline Tetracyclin & $8.62 \pm 1.69$ & $8.90 \pm 0.80$ & $10.07 \pm 0.57$ \\
\hline
\end{tabular}

T a ble 4. Mean fatty acid composition $( \pm s)$ of $B$. cereus strains isolated from different types of food poisoning.

\begin{tabular}{rcc}
\hline & Percentage of fatty acid (mean \pm s). Strains isolated from \\
\cline { 2 - 3 } Fatty acid & $\begin{array}{c}\text { diarrhoeal } \\
\text { type outbreaks } \\
\text { (group 1, Table } 1,\end{array}$ & $\begin{array}{c}\text { vomiting type } \\
\text { outbreaks } \\
\text { (group 2, Table 1, } \\
\text { n = 5) }\end{array}$ \\
\hline br C $13: 0$ & $15.60 \pm 2.16$ & $15.46 \pm 3.89$ \\
br C $14: 0$ & $3.30 \pm 1.07$ & $2.68 \pm 0.43$ \\
n C $14: 0$ & $2.36 \pm 0.66$ & $3.16 \pm 2.39$ \\
br C $15: 0$ & $22.70 \pm 4.16$ & $20.80 \pm 4.38$ \\
n C $15: 0$ & $0.20 \pm 0.00$ & $0.20 \pm 0.00$ \\
br C $16: 0$ & $2.82 \pm 1.12$ & $2.80 \pm 0.77$ \\
n C $16: 0$ & $26.04 \pm 5.88$ & $29.96 \pm 9.78$ \\
br C $17: 0$ & $15.62 \pm 3.01$ & $16.70 \pm 4.45$ \\
n C $17: 0$ & $0.20 \pm 0.00$ & $0.20 \pm 0.00$ \\
br C $18: 0$ & $0.00 \pm 0.00$ & $0.98 \pm 0.90$ \\
n C $18: 0$ & $5.32 \pm 3.08$ & $4.08 \pm 0.86$ \\
n C $18: 1$ & $5.92 \pm 2.40$ & $2.98 \pm 2.85$ \\
\hline
\end{tabular}

position from the other nine strains analysed. The individual fatty acid composition differed by more than two standard errors from the mean of the $\mathbf{1 0}$ strains in the case of four fatty acids.

The mean radii of the areas of vascular permeability due to intracutaneous injection of $B$. cereus culture filtrate or culture 
T a b l e 5. Vascular permeability of rabbit skin after intracutaneous injection of $B$. cereus culture filtrate and culture filtrate concentrate from strains of different origin.

\begin{tabular}{|c|c|c|}
\hline & \multicolumn{2}{|c|}{$\begin{array}{l}\text { Mean radius (in } m m \pm s \text { ) of the } \\
\text { blueing area of the rabbit skin }\end{array}$} \\
\hline & experiment 1 & experiment 2 \\
\hline \multicolumn{3}{|c|}{ Strains from diarrhoeal type outbreaks (group 1 , Table $1, n=5$ ) } \\
\hline - Culture filtrates & $1.48 \pm 0.29$ & $0.95 \pm 0.62$ \\
\hline $\begin{array}{l}\text { - Culture filtrate } \\
\text { concentrates }\end{array}$ & $4.20 \pm 1.48$ & $4.20 \pm 1.72$ \\
\hline \multicolumn{3}{|c|}{ Strains from vomiting type outbreaks (group 2 , Table $1, n=5$ ) } \\
\hline - Culture filtrates & $1.45 \pm 0.57$ & $0.70 \pm 0.27$ \\
\hline $\begin{array}{l}\text { - Culture filtrate } \\
\text { concentrates }\end{array}$ & $4.15 \pm 1.42$ & $3.50 \pm 1.00$ \\
\hline
\end{tabular}

filtrate concentrates prepared from strains originating from diarrhoeal and vomiting type food poisoning outbreaks are presented in Table 5. Every culture filtrate caused a blueing reaction in the skin, the area of which ranged from 0.8 to $12.6 \mathrm{~mm}^{2}$. The respective figures for the culture concentrates were 19.6 and $132.7 \mathrm{~mm}^{2}$. No significant differences were found between the reactions caused by the different strains studied.

\section{DISCUSSION}

The results of the biochemical tests (Table 2) follow the patterns that are considered typical for B. cereus (Goepfert et al. 1972, Gibson \& Gordon 1974, Gilbert \& Taylor 1976). The tendency for strains from vomiting type outbreaks to produce acid from salicin, reported by Gilberg \& Taylor, was found in this study, too. Four of the five isolates from vomiting type food poisoning outbreaks were obtained from Dr. R. J. Gilbert and obviously had been used in his former studies.

No association between an antibiotic sensitivity pattern and the source of a strain could be found in our studies. All the strains tested were resistant to polymyxin, and only one strain (F 3502) was susceptible to penicillin.

Gas chromatographic fatty acid analysis of a $\mathrm{B}$. cereus cell has been used as a diagnostic tool (Niskanen et al. 1975) as well as in epidemiological investigations (Raevuori et al. 1976). With the exception of one strain the gas chromatograms of the 10 
strains analysed in this study (Table 4) followed the general pattern for B. cereus (Niskanen et al.). Strain F 4431 differed considerably from this typical fatty acid composition. According to the results the gas chromatograms cannot be used for distinguishing between $B$. cereus strains isolated from diarrhoeal and vomiting type outbreaks.

Spira \& Goepfert (1972) used the ligated rabbit ileal loop test for the detection of the enterotoxic substance produced by B. cereus. Glatz \& Goepfert (1973) found a good correlation between the results obtained from the loop test and the guineapig skin assay method. The skin test was further developed by Glatz et al. (1974), using rabbit as the test animal. This test correlated very well with the loop test and was more sensitive and also more convenient to carry out. In our study the methodology of Spira \& Goepfert (1975) was followed in the production and concentration of the enterotoxic substance and its detection by the rabbit skin test.

According to the results of this study, no significant differences in the production of the permeability factor between the strains from diarrhoeal and vomiting type outbreaks can be found. Thus the rabbit skin permeability test cannot be used to distinguish between these two aetiologically differing strains. There are differences between the two experiments made for each strain (Table 5). This can be explained to a certain extent by a difference in test animals: an older and heavier animal was used in the second experiment. The difference in the levels of response does not affect the comparative conclusions because only one rabbit was used per experiment.

Melling et al. (1976) were able, by means of the rabbit ileal loop test carried out according to De \& Chatterje (1953), to distinguish between strains isolated from vomiting and diarrhoeal type episodes. According to our findings both of the strains they used (F 4810 and F 4433) were skin-positive, although F 4433 gave a considerably stronger reaction. The skin test is significantly more sensitive than the ileal loop test (Glatz \& Goepfert 1973). Thus it is possible that the strains isolated from vomiting type outbreaks produce amounts of the enterotoxic substance which are too small to be detected by the ileal loop technique, but large enough to give a positive skin response.

The small number of replications (two) in the skin test experiments does not allow for statistically sound conclusions. 
The results, however, indicate that $B$. cereus strains which cause vomiting type food poisoning outbreaks also produce the skin permeability factor. Variations in toxin formation and destruction in different foods and laboratory growth media have been demonstrated for many food poisoning bacteria, including $B$. cereus (Baird-Parker 1971, Ivers \& Potter 1977). For instance B. cereus produces haemolysin and phospholipase $\mathrm{C}$ in pea but only lethal toxin in banana (Ivers \& Potter). Spira \& Goepfert (1972) noticed in their studies of the ileal loop factor that the nature of the bacterial growth medium was important for the toxic response. Certain nutrients are obviously required for the formation of the toxin. Enzyme induction, caused by certain chemicals in the environment, could also explain differences in toxin formation observed in various media. Recently, evidence has accumulated that the vomiting and diarrhoeal type food poisoning are due to the production of two distinct toxins (Turnbull 1976, Melling et al.).

Taylor \& Gilbert (1975) have developed a serotyping scheme for B. cereus. According to studies by Gilbert \& Parry (1977) the selection of strains of particular serotype occurs during the preparation of cooked and fried rice, due evidently to differences in heat resistance or growth rate. Our study did not involve these parameters.

According to the results of this study, B. cereus strains isolated from the vomiting and diarrhoeal types of food poisoning outbreaks do not differ significantly in their biochemical characteristics, antibiotic resistance, fatty acid composition or formation of skin permeability factor in laboratory medium. There are obvious differences in toxin production of $B$. cereus strains isolated from different types of food poisoning outbreaks. In order to study this variation in different foods, immunological methods of detection of the enterotoxic substances must be developed.

\section{REFERENCES}

Baird-Parker, A. C.: Factors affecting the production of bacterial food poisoning toxins. J. appl. Bact. 1971, 34, 181-197.

Beckers, $H$. J.: The bacteriological quality of boiled and fried rice from Chinese restaurants in relation to Bacillus cereus food poisoning. Arch. Lebensmitt.-Hyg. 1976, 27, 66-71.

De, S. N. \& D. N. Chatterje: An experimental study of the mechanism of action of Vibrio cholerae on the intestinal mucous membrane. J. Path. Bact. 1953, 66, 559-562. 
Ezepchuk, Yu. V. \& F. S. Fluer: Isolation and certain properties of Bacillus cereus toxin. (In Russian). J. Microbiol. Epidem. Immunobiol. 1971, 7, 124-131.

Gibson, T. \& R. E. Gordon: Genus Bacillus. In Bergey's Manual of Determinative Bacteriology. R. E. Buchanen \& N. E. Gibbons, eds. 8th Ed. The Williams \& Wilkins Co. Baltimore 1974.

Gilbert, R. J. \& J. M. Parry: Serotypes of Bacillus cereus from outbreaks of food poisoning and from routine foods. J. Hyg. (Lond.) 1977, 78, 69-74.

Gilbert, R. J. \& A. J. Taylor: Bacillus cereus food poisoning. In Microbiology in Agriculture, Fisheries and Food. F. A. Skinner \& J. G. Farr, eds. Acad. Press, London 1976.

Glatz, B. A. \& J. M. Goepfert: Extracellular factor synthesized by Bacillus cereus which evokes a dermal reaction in guinea pigs. Infect. Immunity 1973, 8, 25-29.

Glatz, B. A., W. M. Spira \& J. M. Goepfert: Alteration of vascular permeability in rabbits by culture filtrates of Bacillus cereus and related species. Infect. Immunity 1974, 10, $229-303$.

Goepfert, J. M., W. M. Spira \& H. U. Kim: Bacillus cereus: food poisoning. A review. J. Milk Fd Technol. 1972, 35, 213-227.

Goepfert, J. M., W. M. Spira, B. A. Glatz \& H. U. Kim: Pathogenicity of Bacillus cereus. In The Microbiological Safety of Food. B. C. Hobbs \& J. H. B. Christian, eds. Acad. Press, London 1973.

Gorina, L. G., F. S. Fluer, A. M. Olovnikov \& Yu. V. Ezepchuk: Use of the aggregate-hemagglutination technique for determining exoenterotoxin of Bacillus cereus. Appl. Microbiol. 1975, 29, 201204.

Hauge, S.: Matforgiftninger fremkalt av Bacillus cereus. (Food poisonings caused by Bacillus cereus). Nord. hyg. T. 1950, 31, 189206.

Hunt, G. A., A. Gourebitch \& J. Levin: Preservation of cultures by drying on porcelain beads. J. Bact. 1958, 76, 453-454.

Ivers, J. T. \& N. N. Potter: Production and stability of hemolysin, phospholipase $\mathrm{C}$, and lethal toxin of Bacillus cereus in foods. J. Fd Protection 1977, 40, 17-22.

Johnson, C. E. \& P. F. Bonventre: Lethal toxin of Bacillus cereus. I. Relationships and nature of toxin, hemolysis, and phospholipase. J. Bact. 1967, 94, 306-314.

Lubenau, C.: Bacillus peptonificans als Erreger einer GastroenteritisEpidemie. (Bacillus peptonificans as a causative organism of a gastroenteritis outbreak). Zbl. Bakt., I. Abt Orig. 1906, 40, 433437.

Mathias, R. G., E. Todd, R. Szabo \& D. Martin: Illness from fried rice - St. John's, Newfoundland. Canada Diseases Weekly Report 1976, 2, 78-80.

Melling, J., B. J. Capel, P. C. B. Turnbull \& R. J. Gilbert: Identification of a novel enterotoxigenic activity associated with Bacillus cereus. J. clin. Path. 1976, 29, 938-940. 
Niskanen, A., T. Kiutamo, Y. Mälkki \& E. Nikkilä: Nachweis von Bacillus cereus in Lebensmitteln: Gaschromatographische Analyse der Zusammensetzung der bakteriellen Fettsäuren. (Detection of Bacillus cereus in foods: Gas chromatographic analysis of the bacterial fatty acid composition). Arch. Lebensmitt.-Hyg. $1975,26,15-16$.

Portnoy, B. L., J. M. Goepfert \& S. M. Harmon: An outbreak of Bacillus cereus food poisoning resulting from contaminated vegetable sprouts. Amer. J. Epidem. 1976, 103, 589-594.

Public Health Laboratory Service: Food poisoning associated with Bacillus cereus. Brit. med. J. 1972, 1, 189.

Raevuori, M., T. Kiutamo, A. Niskanen \& K. Salminen: An outbreak of Bacillus cereus food-poisoning in Finland associated with boiled rice. J. Hyg. (Lond.) 1976, 76, 319-327.

Spira, W. M. \& J. M. Goepfert: Bacillus cereus induced fluid accumulation in rabbit ileal loops. Appl. Microbiol. 1972, 24, 341-348.

Spira, W. M. \& J. M. Goepfert: Biological characteristics of an enterotoxin produced by Bacillus cereus. Canad. J. Microbiol. 1975, 21, $1236-1246$.

Taylor, A. J. \& R. J. Gilbert: Bacillus cereus food poisoning: A provisional serotyping scheme. J. med. Microbiol. 1975, 8, 543550.

Turnbull, P. C. B.: Studies on the production of enterotoxins by B. cereus. J. clin. Path. 1976, 29, 941-948.

\section{SAMMANFATTNING}

Jämförande studier över stammar av Bacillus cereus isolerade från olika livsmedel och fall av matförgiftningar.

I detta arbete undersöktes vissa egenskaper hos 22 stammar av Bacillus cereus, isolerade från olika livsmedel och fall av matförgiftning. Meningen var att försöka kartlägga eventuella skillnader mellan stammarna isolerade från matförgiftningar av diarré- och uppkastningstyp.

Alla stammar isolerade från fall av uppkastningstyp producerade inte syra från salicin och mannos, medan 80 och respektive $40 \%$ av stammarna från fall av diarrétyp var positiva. Inga samband mellan antibiotikasensibilitet eller fettsyrasammansättning och källan för en stam kunde påvisas, fastän några stammar i vissa fall avvek från det allmänna mönstret for B. aureus. Någon signifikant skillnad i framkallandet av den s.k. hudfaktorn mellan stammar isolerade från de två olika typerna av matförgiftning kunde inte heller påvisas. Resultaten stöder uppfattningen att miljön i livsmedlen $i$ sig själv i väsentlig grad påverkar bildningen av enterotoxin hos B. cereus.

(Received May 5, 1977).

Reprints may be requested from: M. Raevuori, the State Veterinary Institute, P. O. Box 368, 00101 Helsinki 10, Finland. 